\title{
父親・母親の養育スタイルに関する大学生の 回想とアイデンティティ形成
}

\author{
平田 裕美 女子栄養大学
}

\section{University students' retrospective assessments of the impact of parenting on their identity formation}

\author{
Hiromi Hirata (Kagawa Nutrition University)
}

\begin{abstract}
The impact of parenting on the family orientation of university students and their identity formation during adolescence was investigated to identify parenting styles that promoted identity integration and minimized confusion. In addition, cooperation between fathers and mothers was analyzed to explain parenting styles. The results indicated that students of both genders who were raised by parents with an authoritative style more often evaluated that their parents cooperated in raising them compared with those who were raised with other parenting styles. Moreover, identity integration was significantly higher among students who were raised with an authoritative parenting style than among those raised with an authoritarian and uninvolved parenting style, whereas the opposite outcome was seen for identity confusion. Therefore, it was concluded that in the process of identity formation during adolescence, parenting styles that are responsive to children are essential, as is putting demands on them to mature based on proper criteria, i.e. disciplining them. However, further discussion is required about the fact that no differences were seen for the permissive parenting style.
\end{abstract}

Key words: identity, integration, confusion, parenting style, parenting cooperation.

The Japanese Journal of Psychology

2018, Vol. 89, No. 3, pp. 221-228

J-STAGE Advanced published date: July 14, 2018, doi.org/10.4992/jjpsy.89.16071

青年期の発達課題であるアイデンティティは，自己 の意思決定と成人期以降の軌道を導く「内なるコンパ ス “inner compass”」と称される (Côté, 2000; Côté \& Levine, 2002)。アイデンティティの統合（「私は，自 分が何になりたいのかをはっきりと考えている」）は 自尊感情を高め (Kutkiene, 2008), 情緒を安定させ (Dumas, Lawford, Tieu, \& Pratt, 2009; Sandhu, Singh, Tung, \& Kundra, 2012), アイデンティティの混乱（「私 は, 自分のしていることを本当はわかっていない」) は人格障害や抑うつなどに関連する (Jung, Pick, Schlüter-Müller, Schmeck, \& Goth, 2013)。整理すると, 青年期のアイデンティティは, 統合寄りの状態になる と, 不安や心身の症状と負の相関, 混乱寄りの状態に

Correspondence concerning this article should be sent to: Hiromi Hirata, Developmental Psychology Laboratory, Faculty of Nutrition, Kagawa Nutrition University, Chiyoda, Sakado 350-0288, Japan. (E-mail: hhiromi@eiyo.ac.jp)
なると，正の相関になると予測される。これらの青年 期のアイデンティティの統合と混乱への影響要因には 様々な見解があり，その影響要因の 1 つとして注目さ れているのが家族である。家族は青年期の最も重要な 影響要因である（Steinberg, 2001）との指摘からも, 青年期のアイデンティティ形成への家族, とくに親の 養育効果は大きいと考えられる。

\section{青年期のアイデンティティと家族}

Schwartz, Pantin, Prado, Sullivan, \& Szapocznik (2005) によると, 親の肯定的な養育, コミュニケーション, サポートは青年期の子どものアイデンティティの統合 と正の相関を, アイデンティティの混乱とは負の相関 を示す。Rageliene \& Justickis（2016）は, Bowen（1978） の自己分化と青年期の子どもをもつ親の養育スタイル との関連から, 子どもの意見を考慮せず，服従やルー ルへの順守を要求する親の養育スタイルはアイデン ティティ混乱を, 男子では完全に仲介し，女子では部 
分的に仲介していたと述べている。青年期の子どもへ の親の受容的養育態度 (Sandhu et al., 2012), 温かい 家族関係や適度な強さをもつ家族の凝集性（Van Hoof, Raaijmakers, Van Beek, Hale, \& Aleva, 2008)，そして子 どもから親に向けられた愛着（Nawaz, 2011）などは, 青年期のアイデンティティ形成に肯定的な影響をもつ 要因とされる。Yablonska（2013）も青年期にアイデン ティティが統合される好ましい条件として, 適度な強 さをもつ家族の凝集性と民主的な親の養育スタイルを あげている。このように生まれ育った家族(定位家族, family of orientation）に打ける親の養育は，青年期の アイデンティティの統合と混乱を調整するものとして 理解される。

\section{青年期のアイデンティティと養育スタイル}

Baumrind（1971）は, 親の養育, 親と子どもとのコミュ ニケーションにおける応答性と成熟への要求, 子ども の行動を管理する(しつける)要求性の高低に基づいて, 養育スタイルを権威的養育スタイル (Authoritative parenting style), 権威主義（独裁）的養育スタイル (Authoritarian parenting style), 許容的養育スタイル (Permissive parenting style)の3つに分類している。また, Maccoby \& Martin（1983）は，権威的養育スタイル，権 威主義（独裁）的養育スタイル, 許容的養育スタイル, そして放任的養育スタイル (Uninvolved parenting style) の 4 養育スタイルを提示している。Buri（1991）の尺 度構成によると，権威的に養育する親は民主的な判断 を伴う親であり，子どもとのコミュニケーションを重 視する行動をとると同時に, 子どもへの成熟の要求や しつけに関する適切な基準をもつ。権威主義に基づく 親は，独裁的に判断する傾向があり，子どもへの成熟 の要求も高く，しつけることに厳格な姿勢をもつ。許 容的な親は，子どもとのコミュニケーションを重視す るが，子どもへの成熟の要求や子どもをしつけること には消極的である。そして，子どもを拒否/放任する 親は，受容的な養育態度や子どもとのコミュニケー ションをとろうとせず，子どもへの成熟の要求もしつ けることもしない。さらに, アイデンティティの統合 に近似する概念として，自ら自己成長を成し遂げよう とする認知・行動を示す自己成長主導性（Robitschek, 1998; Robitschek et al., 2012）や, 自尊感情への影響では, 権威的養育スタイルの家庭で育った青年がより肯定的 である（Hirata \& Kamakura, 2017）。青年期の情報処理 スタイルに着目した研究では, 問題に向き合い, 自ら 解決しょうと積極的に情報収集し，有益な情報を選択 できる(情報スタイル)青年と権威的養育スタイルの親, 他者の期待や規範に従い，未経験でも対処するため意 思決定時の混乱が低い（規範スタイル）青年と権威主 義（独裁）的養育スタイルの親，直面した問題の解決 を延期または回避し，一時的対処しかできない（拡散
（回避スタイル）青年と許容的養育スタイルの親との 関係が予測され，特に規範スタイルと権威主義（独裁） 的養育スタイルとの関連が指摘されている（Berzonsky, 1990, 2004)。Baumrind (1991) も, Berzonsky (1990) の 情報処理スタイルに注目し, 情報スタイルの青年は権 威的養育スタイルの家庭で育ったと述べていたことを 報告している。権威的養育スタイルの親に育てられて いた場合は，青年期のアイデンティティは統合寄りに なると考えられる。

\section{本研究の目的}

青年期の成功したアイデンティティ発達とは，アイ デンティティの統合が混乱よりも優位になる程度に操 作されることにある (Erikson, 1968)。Baumrind (1971) や Maccoby \& Martin（1983）が説明する，応答性と要 求性から構成される親の養育スタイルは, 青年期のア イデンティティ形成の統合，あるいは混乱にどのよう に関わっているのか。それを明らかにするために，本 稿では養育スタイル別に，青年期のアイデンティティ 形成（統合・混乱）における差異を検討する。そして, どのような条件時に養育行動はより表出されるのかを 検討するため, 配偶者との養育連携が父親，母親の養 育行動を高めるという知見 (平田, 2003a, 2003b, 2012）に基づき，父親，母親の養育スタイル別に養育 連携における差異を検討する。Schwartz, Mason, Pantin, \& Szapocznik（2009）によると, 青年期のアイ デンティティの混乱は, 青年の自己申告による家族機 能と強く関連している。また, 養育者自身の養育行動 そのものへの評価よりも，養育者の行動を子どもがど のように解釈したり評価したりしているのかが重要で ある（Grusec, 2011）。さらに，児童期までの同一化を 基礎としながらも，青年期にアイデンティティは統合 される（谷，2008）。したがって，家族と同居し，か つ自己に対する客観性が芽生えだした青年期中期の高 校生ごろを定位家族として振り返る時期に限定し，青 年期後期にあたる大学生男女を対象に分析を進める。

\section{方法}

\section{参加者と手続き}

関東圈の大学生 367 名に調查参加を依頼し, 回答に 未記入があった 39 名のデー夕を除外した。そのため 本研究では 328 名 (男子 162 名, 女子 166 名, 平均年 齢 19.6 歳, $S D=1.38$ ）を分析対象とした（調查期間 は2016 年 5-6月)。講義において同意書に署名をし た大学生を対象に質問紙調査を一斉実施した（調査に 要した時間は 20 分程度)。なお，調査実施にあたり， 女子栄養大学倫理審査委員会の承認（第 54 号）を事 前に得ている。 
Table1

養育行動尺度の因子分析

\begin{tabular}{|c|c|c|c|c|c|c|}
\hline & \multicolumn{3}{|c|}{ 父親 } & \multicolumn{3}{|c|}{ 母親 } \\
\hline & F1 & F2 & 共通性 & F1 & $\mathrm{F} 2$ & 共通性 \\
\hline 1. 意見が異なったときは, 私の意見に耳を傾け, 話してくれていた。 & .81 & -.10 & .58 & .82 & -.09 & .62 \\
\hline 2. 私が困ったときや悩んだときは，相談にのってくれていた。 & .73 & .08 & .60 & .83 & -.03 & .67 \\
\hline 3. 私が迷っている時は，考えがまとまるまで待ってくれていた。 & .67 & -.09 & .40 & .67 & -.06 & .41 \\
\hline 4. 一人の人間として，私と対等に接してくれていた。 & .66 & -.12 & .37 & .62 & .00 & .39 \\
\hline 5. 夢や生き方など, 自分の考えを私に話してくれていた。 & .62 & .14 & .49 & .62 & .04 & .41 \\
\hline 6. 私と日常の社会現象や娛楽などの話題で話していた。 & .54 & .11 & .36 & .43 & .20 & .31 \\
\hline $\begin{array}{l}\text { 7. 一緒に（買い物, 食事, 見学・観戦, 散歩など）出かけてくれ } \\
\text { ていた。 }\end{array}$ & .53 & .10 & .33 & .41 & .23 & .31 \\
\hline $\begin{array}{l}\text { 8. 私が失敗などをしたときは, なぐさめたり, 励ましたりしてく } \\
\text { れていた。 }\end{array}$ & .50 & .00 & .24 & .77 & -.02 & .57 \\
\hline $\begin{array}{l}\text { 9. 家族でのルール（家事の役割分担，帰宅時間など）を，私に守 } \\
\text { らせていた。 }\end{array}$ & -.24 & .85 & .58 & -.10 & .83 & .62 \\
\hline 10. 社会の規範（道徳観, お金のルールなど）を, 私に守らせていた。 & .01 & .73 & .53 & -.07 & .82 & .62 \\
\hline 11. 礼儀作法（目上の人への挨拶，言葉づかい）を教えていた。 & .17 & 69 & .61 & .27 & .58 & .56 \\
\hline 12. あいさつなどを含めた基本的生活習慣を守らせていた。 & -.03 & .69 & .46 & .11 & .63 & .48 \\
\hline 13. 私の間違った言動や行動には, 厳しく注意していた。 & .06 & .61 & .41 & -.13 & .83 & .60 \\
\hline 14. しつけについては，毅然とした態度で，私に接していた。 & .13 & .52 & .36 & .14 & .55 & .40 \\
\hline \multirow[t]{3}{*}{ 因子間相関 } & - & & & - & & \\
\hline & 0.47 & - & & 0.48 & - & \\
\hline & 33.56 & 11.64 & & 37.38 & 12.36 & \\
\hline
\end{tabular}

注) F1 応答性, F2 要求性。

\section{質問紙の構成}

養育行動尺度 養育行動尺度については，養育行動 を測る尺度として学齢期から青年期まで, 前原（2012） などで広く使われている, 平田 (2001) による Baumrind（1971）の応答性と要求性の 2 つの次元に基 ついた「父親の青年への関わり行動尺度」の親と子ど もを対象とした改訂版を，過去形の文に変更して用い た (平田, 2003a，2003b，2012)。しかし，「夢や生き 方など, 自分の考えを私に話してくれていた」の項目 は要求性に関する項目として作成されていたが，親を 対象とした場合は要求性に，子どもを対象とした場合 は応答性に含まれる可能性が高い。本稿では大学生を 対象に定位家族である親の養育を尋ねるので，この項 目は応答性に属するものと捉えた。そのため, 親の民 主的な養育，親と子どものコミュニケーションにあた る「意見が異なったときは，私の意見に耳を傾け，話 してくれていた」などの養育行動に負荷量が高い「応 答性: 会話／表現行動」は7 項目から8 項目に, 親の 管理, 成熟への要求である「家庭でのルール（家事の 役割分担，帰宅時間など）を，私に守らせていた」な どの養育行動に負荷量が高い「要求性 : 管理 /成熟へ
の要求行動」は 7 項目から 6 項目に振り替えた。これ より，項目数が異なるため標準化する必要がある。そ れぞれの Z スコアを算出して分析に用いる。

養育連携尺度 父親, 母親の養育行動の規定因とし て，配偶者との養育における連携が仮定されている。 本稿に拈いても，平田 (2001，2003a，2003b，2012） の「家族の問題（子ども／私への教育やしつけを含め て）については夫婦で／父／母と話し合っている」な ど，配偶者との養育に関する意見交換，配偶者を頼り にする, 協力する行動を測る「養育連携尺度」6 項目 を過去形の文に変更して用いた。

Erikson Psychosocial stage inventory の第 5 段階邦 訳版 アイデンティティ形成（統合・混乱）を測る尺 度として, Erikson Psychosocial stage inventory の第 5 段階邦訳版「エリクソン心理社会的段階目録: 第 5 段 階（畑野・杉村・中間・溝上・都築，2014）」を用いた。 この尺度は「私は, 自分が何になりたいかをはっきり と考えている」などの統合 6 項目,「私は, 人生をど のように生きたいのかを自分で決められない」などの 混乱 6 項目から構成されている。

これらの項目は，すべて「全くそう思わない」から 「かなりそう思う」の 5 件法で回答を求めた。 
Table 2

養育連携尺度の因子分析

\begin{tabular}{|c|c|c|c|c|}
\hline & 父親 & 共通性 & 母親 & 共通性 \\
\hline 1 私の相談相手として, 父/母はふさわしいと考えていた。 & .76 & .58 & .78 & .61 \\
\hline 2 私を育てる方針について, 父／母と考えが一致していた。 & .74 & .55 & .68 & .47 \\
\hline 3 私を育てることについて, 父 /母の考えを尊重していた。 & .73 & .53 & .86 & .74 \\
\hline 4 私に関することを，父／母に聞いたり，話したりしていた。 & .67 & .45 & .72 & .51 \\
\hline 5 私を育てることについて, 父／母を頼りにしていた。 & .65 & .43 & .82 & .67 \\
\hline $\begin{array}{l}6 \text { 家族の問題（私への教育やしつけを含めて）については, 父/母と話し合っ } \\
\text { ていた。 }\end{array}$ & .50 & .25 & .66 & .43 \\
\hline
\end{tabular}

寄与率（\%） 46.47

57.28

Table 3

クラスタ別養育スタイル

\begin{tabular}{llrccc}
\hline Cluster & & 全体 & 男子 / 女子 & 応答性 & 要求性 \\
\hline 父親 & 1 権威 & 93 & $40 / 53$ & 4.29 & 4.44 \\
& 2 権威主義 (独裁) & 80 & $44 / 36$ & 2.74 & 3.90 \\
& 3 許容 & 109 & $63 / 46$ & 3.73 & 3.20 \\
& 4 放任 & 46 & $15 / 31$ & 2.49 & 2.10 \\
\hline 母親 & 1 権威 & 119 & $40 / 79$ & 4.55 & 4.68 \\
& 2 権威主義 (独裁) & 99 & $63 / 36$ & 3.49 & 4.05 \\
& 3 許容 & 72 & $37 / 35$ & 4.17 & 3.19 \\
& 4 放任 & 38 & $22 / 16$ & 2.57 & 2.74 \\
\hline
\end{tabular}

養育行動尺度, 養育連携尺度 養育行動, 養育連携 を測るために, 養育行動尺度, 養育連携尺度を用いた。 この尺度は,「高校生の頃，あなたのお父さんは」，「高 校生の頃，あなたのお母さんは」というように，父親 と母親に関する質問を別々の枠組みで尋ねた。

学年, 性別, 年齢, 家族構成, 現在の住居形態など 調査参加者の属性に関する質問は, フェイスシートに まとめて，記入を依頼した。

\section{結果}

最初に天井効果や床効果のチェックを行った（ $M \pm$ $1 S D$ が最大值，最小值を超える項目）が，どの項目に おいても見られなかった。父親, 母親の養育行動尺度, 養育連携尺度に因子分析（主因子法, promax 回転) を施した。

父親の養育行動では第 1 因子の寄与率が $33.56 \%$, 第 2 因子の寄与率が $11.64 \%$ ，母親の養育行動では第 1 因子の寄与率が $37.38 \%$, 第 2 因子の寄与率が $12.36 \%$ であったことから，2 因子構造が確認された。 第 1 因子「応答性：会話 /表現行動」, 第 2 因子「要 求性：管理 /成熟への要求行動」の Cronbach の $\alpha$ 係 数は, 父親の応答性: 会話/表現行動が.84, 要求性 : 管理 /成熟への要求行動が.84, 母親の応答性 : 会話 ／表現行動が.86, 要求性 : 管理 /成熟への要求行動
が.87と,これまでと同様に極めて高い内的整合性が 認められた（Table 1)。また養育連携尺度についても， 父親の第 1 因子の寄与率が $46.47 \%$ ，母親の第 1 因子 の寄与率が $57.28 \%$ であったことから，第 1 因子の寄 与率の高さ, および固有值落差により, 単因子構造が 確認された。Cronbachの $\alpha$ 係数は, 父親が.83, 母親 が.87 と，かなり高い内的整合性が理解された（Table 2)。エリクソン心理社会的段階目録: 第 5 段階の邦訳 版についても Cronbach の $\alpha$ 係数を算出したところ, 統合が.74, 混乱が.76と, 満足のいく内的整合性が 確認された。

\section{父親・母親の養育スタイル}

大学生が評価する応答性 : 会話／表現行動（以下, 応答性とする）Zスコア，大学生が評価する要求性 : 管理 /成熟への要求行動（以下, 要求性とする） Z ス コアを変数にして，養育のタイプを分類するため，非 階層的クラス夕分析を施した。類似した性質からクラ ス夕にまとめる際の切り捨てを最小限にとどめるため にWard 法を採用した。Baumrind (1971) は3スタイ ルなので，3類型を最初に想定し， クラスタに分けた ところ, 修正 $R^{2}$ 值は.43であった。結果を見ると, 応答性, 要求性の両得点が平均より高い群, 中間の群, 低い群が存在した。これにより, 応答性も要求性も平 
Table 4

性別間, 父親養育スタイル間による養育連携, アイデンティティの差異に関する分散分析の結果

\begin{tabular}{|c|c|c|c|c|c|c|c|c|}
\hline & & \multicolumn{2}{|c|}{ 男子 } & \multicolumn{2}{|c|}{ 女子 } & \multirow{2}{*}{ 性の主効果 } & \multirow{2}{*}{ 養育の主効果 } & \multirow{2}{*}{ 交互作用 } \\
\hline & & $M$ & $S D$ & $M$ & $S D$ & & & \\
\hline \multicolumn{9}{|c|}{ アイデンティティ統合 } \\
\hline 性別 & & 3.25 & 0.06 & 3.29 & 0.06 & $n s$ & & $n s$ \\
\hline \multirow[t]{4}{*}{ 養育スタイル } & 1 権威 & 3.53 & 0.11 & 3.33 & 0.10 & & $1>4 *$ & \\
\hline & 2 権威主義（独裁） & 3.24 & 0.11 & 3.24 & 0.12 & & & \\
\hline & 3 許容 & 3.20 & 0.09 & 3.49 & 0.10 & & & \\
\hline & 4 放任 & 3.01 & 0.18 & 3.10 & 0.13 & & & \\
\hline \multicolumn{9}{|c|}{ アイデンティティ混乱 } \\
\hline 性別 & & 2.70 & 0.70 & 2.62 & 0.06 & $n s$ & & $n s$ \\
\hline \multirow[t]{4}{*}{ 養育スタイル } & 1 権威 & 2.43 & 0.12 & 2.45 & 0.11 & & $2,4>1 * *$ & \\
\hline & 2 権威主義（独裁） & 2.81 & 0.12 & 2.68 & 0.13 & & & \\
\hline & 3 許容 & 2.79 & 0.10 & 2.43 & 0.11 & & & \\
\hline & 4 放任 & 2.74 & 0.20 & 2.94 & 0.14 & & & \\
\hline \multicolumn{9}{|l|}{ 養育連携 } \\
\hline 性別 & & 3.34 & 0.07 & 3.63 & 0.06 & $* * *$ & & $n s$ \\
\hline \multirow[t]{4}{*}{ 養育スタイル } & 1 権威 & 3.80 & 0.12 & 4.04 & 0.10 & & $1>2,3,4 * * *$ & \\
\hline & 2 権威主義（独裁） & 3.16 & 0.11 & 3.42 & 0.12 & & $3>4 * * *$ & \\
\hline & 3 許容 & 3.37 & 0.09 & 3.71 & 0.11 & & & \\
\hline & 4 放任 & 3.02 & 0.19 & 3.33 & 0.13 & & & \\
\hline
\end{tabular}

注） ns は有意ではないことを示す。

$* p<.05, * * p<.01, * * * p<.001$

均よりかなり低い放任群があると考えた。クラス夕数 を 4,5 と変化させると, 4 クラス夕の場合, 応答性 と要求性がともに低い群が出現した。そこで, 本稿で は 4 クラスタを採用することとした（修正 $R^{2}=.57 ） 。$ 各クラス夕の性質より, 先行研究の見解に基づいた養 育スタイルの名称とし, 人数と応答性, 要求性の平均 值を父親，母親別に Table 3 に示す。

\section{父親の養育スタイル別に見た差異}

性別間, 養育スタイル間による大学生のアイデン ティティと大学生が評価する父親の養育連携（以下, 父親の養育連携とする）の差異を検討するために，養 育スタイルと性別を説明変数とし，従属変数をアイデ ンティティ統合, 混乱, そして父親の養育連携とした 二元配置分散分析を行った（Table 4)。最初に，交互 作用から検討したが，すべてに有意な差は認められな かった。まず，大学生のアイデンティティの統合と混 乱について, 前者の統合では, 性の単純主効果は認め られなかったが, 養育スタイルの単純主効果 $(F(3$, $320)=3.01, p<.05)$ が有意であった。同様に, 父 親の養育スタイル間の統合の平均值の差を検討するた めに多重比較を行った。権威的養育スタイルは放任的 養育スタイルよりも統合の平均值が有意に高いと示さ
れた。後者の混乱でも, 性の単純主効果は認められな かったが, 養育スタイルの単純主効果 $(F(3,320)=$ $3.38, p<.01 ）$ が有意であった。父親の養育スタイル 間の混乱の平均值の差を検討するための多重比較の結 果, 権威的養育スタイルが権威主義（独裁）的養育ス タイル, 放任的養育スタイルよりも混乱の平均值が有 意に低いことが示された。父親の養育連携では, 性の 単純主効果 $(F(1,320)=10.53, p<.001)$ と養育又 タイルの単純主効果 $(F(3,320)=14.29, p<.001)$ が共に有意であった。父親の養育連携の性別間の平均 值より, 男子よりも女子の方が有意に高いことが確認 された。また, 養育スタイルの単純主効果が有意であっ たことから, 養育スタイル間の養育連携の平均値の差 を検討するために多重比較を行った。結果, 権威的養 育スタイルは他の養育スタイルよりも父親の養育連携 の平均值が有意に高いこと, 許容的養育スタイルは放 任的養育スタイルよりも父親の養育連携の平均值が有 意に高いことが示された。

\section{母親の養育スタイル別に見た差異}

性別間, 養育スタイル間による大学生のアイデン ティティと大学生が評価する母親の養育連携（以下, 母親の養育連携とする）の差異を検討するために, 養 
Table 5

性別間, 母親養育スタイル間による養育連携, アイデンティティの差異に関する分散分析の結果

\begin{tabular}{|c|c|c|c|c|c|c|c|c|}
\hline & & \multicolumn{2}{|c|}{ 男子 } & \multicolumn{2}{|c|}{ 女子 } & \multirow{2}{*}{ 性の主効果 } & \multirow{2}{*}{ 養育の主効果 } & \multirow{2}{*}{ 交互作用 } \\
\hline & & $M$ & $S D$ & $M$ & $S D$ & & & \\
\hline \multicolumn{9}{|c|}{ アイデンティティ統合 } \\
\hline 性別 & & 3.24 & 0.06 & 3.21 & 0.06 & $n s$ & & $n s$ \\
\hline \multirow[t]{4}{*}{ 養育スタイル } & 1 権威 & 3.57 & 0.11 & 3.43 & 0.08 & & $1>2,4^{*}$ & \\
\hline & 2 権威主義（独裁） & 3.23 & 0.09 & 3.17 & 0.12 & & & \\
\hline & 3 許容 & 3.16 & 0.12 & 3.36 & 0.12 & & & \\
\hline & 4 放任 & 3.02 & 0.15 & 2.88 & 0.17 & & & \\
\hline \multicolumn{9}{|c|}{ アイデンティティ混乱 } \\
\hline 性別 & & 2.69 & 0.07 & 2.67 & 0.07 & $n s$ & & $n s$ \\
\hline \multirow[t]{4}{*}{ 養育スタイル } & 1 権威 & 2.43 & 0.12 & 2.49 & 0.09 & & $2,4>1 * *$ & \\
\hline & 2 権威主義（独裁） & 2.87 & 0.10 & 2.71 & 0.13 & & & \\
\hline & 3 許容 & 2.69 & 0.13 & 2.51 & 0.13 & & & \\
\hline & 4 放任 & 2.77 & 0.17 & 2.98 & 0.19 & & & \\
\hline \multicolumn{9}{|l|}{ 養育連携 } \\
\hline 性別 & & 3.25 & 0.07 & 2.98 & 0.07 & $* * *$ & & $n s$ \\
\hline \multirow[t]{4}{*}{ 養育スタイル } & 1 権威 & 4.02 & 0.13 & 3.58 & 0.09 & & $1>2,3,4^{* * *}$ & \\
\hline & 2 権威主義（独裁） & 3.15 & 0.10 & 3.11 & 0.13 & & $2>4 * * *$ & \\
\hline & 3 許容 & 3.15 & 0.13 & 2.94 & 0.14 & & & \\
\hline & 4 放任 & 2.67 & 0.17 & 2.27 & 0.20 & & & \\
\hline
\end{tabular}

注） $n s$ は有意ではないことを示す。

$* p<.05, * * p<.01, * * * p<.001$

育スタイルと性別を説明変数とし, 従属変数をアイデ ンティティ統合, 混乱, そして母親の養育連携とした 二元配置分散分析を行った（Table 5)。交互作用につ いては, 母親においても有意な差は認められなかった。 まず，大学生のアイデンティティの統合と混乱につい て, 前者の統合では, 性の単純主効果は認められなかっ たが, 養育スタイルの単純主効果 $(F(3,321)=6.78$, $p<.05 ）$ が有意であった。同様に，母親の養育ス夕 イル間の統合の平均值の差を検討するために多重比較 を行った。権威的養育スタイルは権威主義（独裁）的 養育スタイルと放任的養育スタイルょりも統合の平均 值が有意に高いと示された。後者の混乱でも, 性の単 純主効果は認められなかったが, 養育スタイルの単純 主効果 $(F(3,321)=4.32, p<.01)$ が有意であった。 母親の養育スタイル間の混乱の平均值の差を検討する ための多重比較の結果, 権威的養育スタイルが権威主 義（独裁）的養育スタイル, 放任的養育スタイルより も混乱の平均值が有意に低いことが示された。母親の 養育連携では, 性の単純主効果 $(F(1,321)=7.33, p$ $<.001)$ と養育スタイルの単純主効果 $(F(3,321)=$ $30.61, p<.001)$ が共に有意であった。母親の養育連 携の性別間の平均值より，女子よりも男子の方が有意 に高いことが確認された。また, 養育スタイルの単純
主効果が有意であったことから, 養育スタイル間の養 育連携の平均值の差を検討するために多重比較を行っ た。結果, 権威的養育スタイルは他の養育スタイルよ りも，母親の養育連携の平均值が有意に高いこと, 権 威主義（独裁）的養育スタイルは放任的養育スタイル よりも母親の養育連携の平均值が有意に高いことが示 された。

\section{考察}

本研究では, 青年期後期にあたる大学生男女を対象 に, 定位家族における父親, 母親の権威的養育スタイ ル, 権威主義（独断）的養育スタイル, 許容的養育ス タイル，そして放任的養育スタイルが，青年期のアイ デンティティの統合，あるいは混乱にどのように関 わっているのかを検討した。結果, 権威的養育スタイ ルの父親，母親に育てられたと回想する大学生は，放 任的養育スタイルの父親に育てられたと回想する大学 生, 権威主義 (独裁) 的養育スタイル, 放任的養育ス タイルの母親に育てられたと回想する大学生よりも統 合が有意に高く, 権威主義（独裁）的養育スタイル, 放任的養育スタイルの父親，母親に育てられたと回想 する大学生よりも混乱が有意に低いことが明らかにさ れた。コミュニケーションを主とした受容的な養育に 
関する先行研究の見解 (Sandhu et al., 2012; Schwartz et al., 2005）にてらせば, 許容的養育スタイルの父親, 母親も青年期のアイデンティティを統合寄りに促すは ずである。しかしながら，統合にとって有益であると 認められた養育スタイルは権威的養育スタイルのみで あった。この結果より，青年期のアイデンティティが 統合寄りになり，混乱を防ぐには，応答性にあたる養 育行動だけではなく, 応答性とのバランスが取れた要 求性, すなわち明確な基準のもとに適切に子どもをし つける養育行動が父親，母親両者に必要であるという ことが認められた。現在の正の強化に偏った養育への 課題が得られたと考える。

今回の許容的養育スタイルの親は, 子どもと関わる 意識や行動は高いが, 社会の規範やルールを教えるな どの行動や意識は低い。楽しい時間のみを共有しよう とする, 友だちのような親である情緒中心型の親と, 子どもに関わろうとする意識は高いのだが, 実際の行 動が伴わない有言不実行型の親（平田, 2003a）から 構成された可能性がある。両者ともに要求性は低いと いう共通の特徵をもつが, 情緒中心型の親は相手の立 場で考えることはできても潜在化した不満や怒りか ら，あえて子どもに嫌われるようなこと（しつけ）は しない。一方, 有言不実行型の親は, 自分自身の親と の関わりが少なかった経験から養育モデルが希薄であ るため，親として，どのように子どもに関われば良い のか困惑しつつ, 模索しながらも関わろうとする。そ のため, 両者は要求性に対する考えが異なるのではな いか。なお，権威的養育ス夕イルの父親，母親に育て られたと回想する大学生は, 他の養育スタイルの親に 育てられたと回想する大学生よりも, 父と母の養育連 携は高いと評価していた。平田 (2003a，2003b，2012） の知見を支持する結果であった。大学生からの評価で はあるが，配偶者と連携して子どもを育てているとい う考えは，父親，母親の親としての民主的な養育，子 どもとのコミュニケーションを重視する行動や子ども への成熟の要求, しつけに関する適切な基準をもつ行 動につながると理解できる。さらに，許容的養育ス夕 イルの父親, 権威主義 (独裁) 的養育スタイルの母親 であったと回想している大学生は, 放任的養育ス夕イ ルの父親，母親であったと回想している大学生よりも 「協力して私を育ててくれていた」と評価していた。 この差異より，配偶者である妻との養育連携は，父親 の民主的な判断や表現の温かさ，コミュニケーション を，配偶者である夫との養育連携は，母親の子どもへ の適切な基準に基づいた成熟の要求やしつける行動を 促進させる可能性が考えられる。

\section{本研究の限界と課題}

ここで, 本研究の限界と課題についても述べておく。 1 つめは, 応答性による青年期のアイデンティティ
形成における統合に向けた影響力より，応答性と要求 性は相互に関連性を有し影響力をもつことが十分に考 えられることである。父親，母親の応答性に配慮した 量的・質的検討を行う必要がある。

2 つめは, 母親の場合に限り, 権威主義 (独裁) 的 養育スタイルよりも権威的養育スタイルの方が有意に 青年期のアイデンティティを統合寄りにしていたこと である。父親には見られなかった結果であるため, こ れについては権威的養育スタイルと権威主義（独裁） 的養育スタイルの相違を性差の視点から, より具体化 する研究デザインが待たれる。

3 つめは, 養育連携について, 父親, 母親を対象と した個人，または集団面接などの質的調査による検討 が必要なことである。父親，母親の子育てにおける共 通認識や互いの養育に対する考えは, その養育行動だ けではなく，個々の家族成員や家族の在り方そのもの に影響を及ぼすことが先行研究からも予測される。実 際の父親，母親それぞれの認識におけるずれや一致度 などから, 養育スタイルを見極めることが重要である。

4 つめは，青年期では男女共に，男子では母親（男 子から見て異性の親)の父親 (男子から見て同性の親) への態度，女子では父親（女子から見て異性の親） の母親（女子から見て同性の親）への態度が父親, 母親それぞれへの「互いを子どもの養育において頼 りになる存在だと考えていた」という評価につながっ ていたことである。青年期の子どもの性差と親の性 差の両者に着目した, 父親, 母親の養育機能に焦点 をあてた検討が望まれる。養育の質により, 父親, 母親のどちらが担う方が，より良く子どもに受け入 れられるのか, より適任であるのかという点が明ら かになると思われる。

最後は，青年期の子どものアイデンティティが統合 寄りに形成され，混乱を防ぐには，権威的養育ス夕イ ルの父親，母親の関わりが重要であるという結果に関 連した課題である。前述の Erikson（1968）の「アイ デンティティの統合が混乱よりも優位になる程度に操 作される」鍵は定位家族における父親, 母親の養育ス タイルにあると言っても過言ではないだろう。また, 子ども側の評価ではあるが, アイデンティティの統合 に有益な権威的養育スタイルの父親，母親は養育連携 が高いということも確認された。今後は児童期から成 人期までなど，可能な限り発達段階における時間軸を 広げ, 日本の文化を考慮した親の養育スタイルと青年 期のアイデンティティに関わるトランスナショナルな 比較調査を試みるべきである。

\section{引用文献}

Baumrind, D. (1971). Current patterns of parental authority. Developmental Psychology Monographs, 4(1, pt.2). 
$1-103$.

Baumrind, D. (1991). Parenting styles and adolescent development. In J. Brooks-Gunn, R. Lerner, \& A. C. Petersen (Eds.), The encyclopedia of adolescence (pp. 746-758). New York: Garland.

Berzonsky, M. D. (1990). Self-construction over the lifespan: A process perspective on identity formation. In G. J. Neimeyer \& R. A. Neimeyer (Eds.), Advances in personal construct psychology (vol. 1, pp. 155-186). Greenwich: JAI Press.

Berzonsky, M. D. (2004). Identity style, parental authority, and identity commitment. Journal of Youth and Adolescence, 33, 213-220.

Bowen, M. (1978). Family therapy in clinical practice. New York: Library of Congress Catalog.

Buri, J. R. (1991). Parental authority questionnaire. Journal of Personality Assessment, 57, 110-119.

Côté, J. E. (2000). Arrested adulthood: The changing nature of maturity and identity. New York: New York University Press.

Côté, J. E., \& Levine, C. G. (2002). Identity formation, agency, and culture: A social psychological synthesis. Mahwah, NJ: Lawrence Erlbaum.

Dumas, T. M., Lawford, H., Tieu, T. T., \& Pratt, M. W. (2009). Positive parenting in adolescence and its relation to low point narration and identity status in emerging adulthood: A longitudinal analysis. Developmental Psychology, 45, 1531-1544.

Erikson, E. H. (1968). Identity: Youth and crisis. New York: Norton.

Grusec, J. E. (2011). Socialization processes in the family: Social and emotional development. Annual Review of Psychology, 62, 243-269.

畑野 快 - 杉村和美 - 中間 玲子 - 溝上 慎一 - 都築 学 (2014). エリクソン心理社会的段階目録（第 5 段 階） 12 項目版の作成 心理学研究，85, 482-487.

平田 裕美 (2001). 父親の青年への関わり行動尺度の 作成及び信頼性，妥当性の検討——青年期前期の 子どもをもつ父親を中心として——お茶の水女 子大学人間文化論叢, 3,293-301.

平田 裕美 (2003a). 父親の養育行動と高校生の子ど もの精神的健康一一親の養育行動との直接比較 お茶の水女子大学 21 世紀 COE プログラム 「誕生から死までの人間発達科学」平成 15 年度公 募研究成果論文, 2,71-80.

平田 裕美 (2003b)。青年期前期の子どもに対する父 親の関わり—分類と特性——家族心理学研 究, 17, 35-34.

平田 裕美 (2012).母親の就労が高校生の子どもへの 養育行動に及ぼす影響——親と子どもの「好感 感情」と父親との協力関係——応用心理学研究, $38,106-113$.

Hirata, H., \& Kamakura, T. (2017). The effects of parenting styles on each personal growth initiative and self-esteem among Japanese university students. International Journal of Adolescence and Youth. Advance online publication. doi:10.1080/02673843.2017.1371614
Jung, E., Pick, O., Schlüter-Müller, S., Schmeck, K., \& Goth, K. (2013). Identity development in adolescents with mental problems. Child and Adolescent Psychiatry and Mental Health, 7(26). doi:10.1186/1753-2000-7-26

Kutkienè, L. (2008). 16-17 metų paauglių vaikinų ir merginų asmenybės tapatumo brandos ypatumai bei sąsajos su savęs vertinimu. Pedagogika, 90, 109-114. (In Lithuanian)

Maccoby, E. E., \& Martin, J. A. (1983). Socialization in the context of the family: Parent-child interaction. In P. H. Mussen (Ed.), Handbook of child Psychology: Vol.4. Socialization, personality, and social development (4th ed., pp. 1-101). New York: Wiley.

前原 敬子 (2012). 学童期後期の子供への父親の関わ り類型と発達との関連 母性衛生, 53, 116-124.

Nawaz, S. (2011). The relationship of parental and peer attachment bonds with the identity development during adolescence. Journal of Social Sciences, 5, 104-119.

Rageliene, T., \& Justickis, V. (2016). Interrelations of Adolescent's identity development, differentiation of self and parenting style. Psichologija, 53, 24-43.

Robitschek, C. (1998). Personal growth initiative: The construct and its measure. Measurement and Evaluation in Counseling and Development, 30, 183-198.

Robitschek, C., Ashton, M. W., Spering, C. C., Geiger, N., Byers, D., Schotts, G. C., \& Thoen, M. A. (2012). Development and psychometric evaluation of the Personal Growth Initiative Scale-II. Journal of Counseling Psychology, 59, 274-287.

Sandhu, D., Singh, B., Tung, S., \& Kundra, N. (2012). Adolescent identity formation, psychological well-being, and parental attitudes. Pakistan Journal of Psychological Research, 27, 89-105.

Schwartz, S. J., Mason, C. A., Pantin, H., \& Szapocznik, J. (2009). Longitudinal relationships between family functioning and identity development in Hispanic adolescents. Journal of Early Adolescence, 29, 77-211.

Schwartz, S. J., Pantin, H., Prado, G., Sullivan, S., \& Szapocznik, J. (2005). Family functioning, identity, and problem behavior in Hispanic immigrant early adolescents. Journal of Early Adolescence, 25, 392-420.

Steinberg, L. (2001). We know some things: Parentadolescent relationships in retrospect and prospect. Journal of Research on Adolescence, 11, 1-19.

谷冬彦 (2008). 自我同一性の人格発達心理学 ナカ ニシヤ出版

Van Hoof, A., Raaijmakers, Q., Van Beek, Y., Hale, W., \& Aleva, L. (2008). A multi-mediation model on the relations of bullying, victimization, identity, and family with adolescent depressive symptoms. Journal of Youth Adolescence, 37, 772-782.

Yablonska, T. (2013). Family factors of person's identity development during adolescence and early adulthood. Social Welfare Interdisciplinary Approach, 3, 31-42.

- 2017.3.9 受稿, 2018. 1. 20 受理 